\title{
Worries about agreement on trade with Japan
}

Washington and Tokyo

Just two months after the United States and Japan signed a comprehensive agreement governing trade in semiconductors, the US semiconductor industry is accusing Japanese companies of violating the agreement by dumping memory chips on world markets below their "fair market value".

The agreement, reached after months of negotiations, requires Japan to prevent its industry from selling below cost, or dumping, erasable programmable readonly memories (EPROMs) and dynamic random-access memories (DRAMs) on world markets. Japan also agreed to help US companies to achieve more than the 10 per cent share of the Japanese market they now enjoy.

In exchange, the United States agreed to drop two anti-dumping suits that would have levied large import duties on Japanese EPROMs and DRAMs. The United States also ended an investigation into unfair trading practices by Japan that could have resulted in trade retaliation.

The US industry is satisfied that Japanese chips are no longer being sold on the US market at unfair prices. But it says dumping continues in other international markets. The industry claims to have proof of Japanese chips being dumped in Hong Kong; it is also upset by chip prices in Japan itself, where 256k DRAMs can be purchased for as little as Y280 $(\$ 1.80)$, below the figures for fair market value established when the agreement was signed.

Although the agreement does not extend to Japan's domestic market, US officials say they might take action if the low prices prevent growth of US companies' market share in violation of the agreement. The irony of the United States trying to regulate Japanese domestic prices has not been lost on US trade officials.

When the agreement became effective last August, the US Department of Commerce estimated that some Japanese companies were selling their chips in the United States at less than half their cost, so that prices were expected to rise after the agreement took effect. They did, but not dramatically. Dataquest Inc., a semiconductor information service, says $256 \mathrm{k}$ DRAMs cost $\$ 2.40$ before 1 August, but rose only to $\$ 2.85$ afterwards. It is now possible to buy $256 \mathrm{k}$ DRAMs from a US retail distributor for only $\$ 2.75$.

\section{Sino-British collaboration in Tibet}

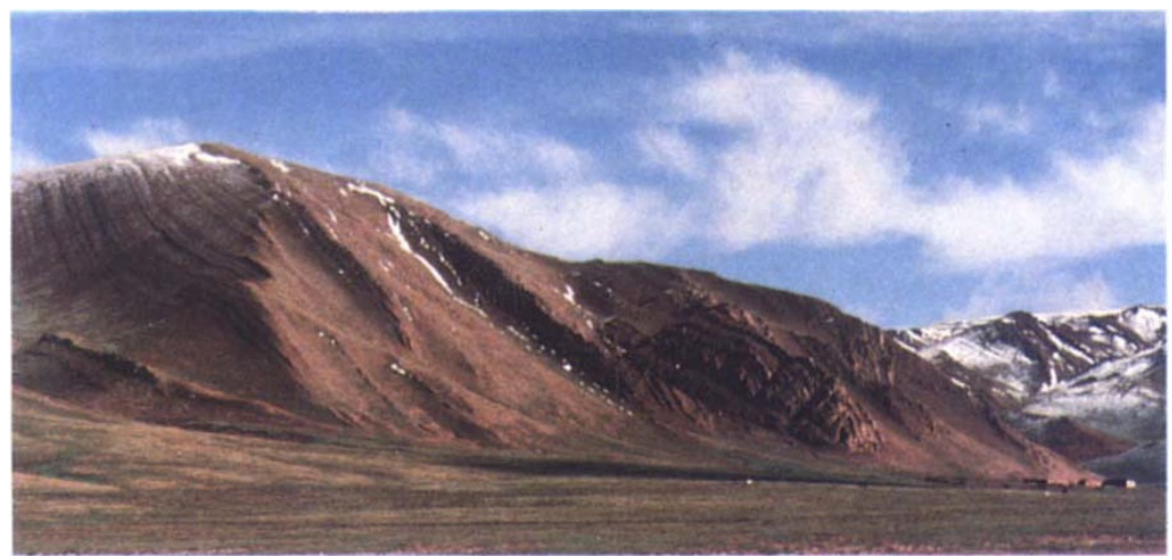

LAST year, the British Royal Society and Chinese Academia Sinica jointly supported an expedition to the Tibetan plateau, and the preliminary results are published today (see p. 501). The low hills above (altitude $5,050 \mathrm{~m}$ ) are composed of red sandstones that were deposited on the Qiangtang Terrane, a continental fragment that collided with the southern Eurasian continental margin about 200 million years ago. The Chinese-British expedition identified three such fragments along their traverse, which followed the 1,150-km-long Lhasa-Golmud highway. The sandstones shown here were deposited about 50 million years ago, as a result of intracontinental shortening during the collision of India with Tibet. One of the major results of the expedition is that the thickening of the Tibetan plateau crust can be explained by such internal shortening, and does not require extensive underthrusting of the plateau by Indian continental crust.
Prices in Japan, in contrast, plummeted by nearly 11 per cent in the past month according to a report in Japan's leading economic newspaper, the Nihon Keizal Shimbun, and further falls are expected due to decreased demand, users' demands for lower prices and a surplus of chips created by the agreement - trading companies saddled with chips they could not sell because of increased export prices have unloaded their excess inventory on the domestic market driving down prices to as low as Y250 $(\$ 1.80)$, far below the "fair market values" of $\$ 2.50-7.00$ stipulated in the agreement.

At the end of this week, the Commerce Department will release to Japanese companies revised figures for the fair market value of the chips covered by the agreement. Those new figures will be effective until the end of 1986, and are expected to be lower than the estimates originally used to conclude the trade agreement. For example, fair market values for $256 \mathrm{k}$ DRAMs were expected to range among manufacturers from $\$ 2.00$ to $\$ 4.00$.

Commerce deputy under-secretary Gilbert Kaplan nevertheless disputes the industry's claim that there are problems with the agreement. Initial enquiries about sales to countries other than the United States were answered "very satisfactorily", he says. The first of the regular consultations called for in the agreement could take place as soon as the end of this month. Kaplan insists that the emergency consultations sought by the US industry are unnecessary.

The agreement was given a vote of confidence last week, when the Idaho-based Micron Technologies dropped a large anti-dumping lawsuit against six Japanese manufacturers. Joe Parkinson, president of Micron Technologies, says his company dropped its suit because he believes the agreement will work

Not all elements of the US industry are enthusiastic about the semiconductor agreement. The Computer and Business Equipment Manufacturers Association. whose members are major users of memory chips, fears that large price increases will result from the agreement. The association is also concerned that the Commerce Department will be hard pressed to gather all the data necessary to prepare accurate estimates of the fair market value of Japanese chips. Meanwhile, the main beneficiaries of the agreement appear to be Japanese computer manufacturers who are enjoying rock-bottom prices in Japan. Ken Flamm of the Brookings Institution in Washington believes that if the Commerce Department's calculations of fair market values are not close to the mark, there will inevitably be problems. He says that if regulated price differential gets too large. "that's when smuggling develops".

Joseph Palca \& David Swinbanks 